\title{
Quality control and anticholinesterase activity determinations on Sternbergia sicula
}

\author{
Derya Çiçek ${ }^{1}$, Nehir Ünver Somer ${ }^{1}$, Gülen İrem Kaya1
}

\begin{abstract}
Aerial and underground parts of Sternbergia sicula Tineo ex Guss., growing in Söke (Aydın), were collected during two different vegetation periods, namely flowering and fruting seasons. Quality control studies and anticholinesterase activity determinations were carried out on the prepared specimens. In the course of the quality control studies, assays for humidity, total ash, hydrochloric acid-insoluble ash and sulphated ash were performed on drug specimens prepared separately from plants collected in flowering and fruiting stages.The humidity, total ash, hydrochloric acid-insoluble ash and sulphated ash contents of the specimens ranged between $7.828-8.798 \%, 7.086-16.924 \%, 1.120-4.340 \%$ and $11.102-$ $23.465 \%$, respectively. The total alkaloid contents of Sternbergia sicula specimens were determined by a titrimetric method. The amount of total alkaloids ranged between 0.122 $0.496 \%$. The highest content of total alkaloids was found in herba of S. sicula collected during flowering period. The lowest content of total alkaloids were detected in herba of S. sicula collected during fruiting period. Moreover, anticholinesterase activity of the total alkaloid extracts, prepared from drug specimens, were determined by Thin Layer Chromatography (TLC) assay, based on in vitro Ellman method. All of the alkaloidal extracts showed anticholinesterase activity.
\end{abstract}

KEY WORDS: Sternbergia sicula, Amaryllidaceae, Quantitative Determination, Anticholinesterase Activity

\section{INTRODUCTION}

Sternbergia Waldst \& Kit. (winter daffodil) (Amaryllidaceae) is represented by 6 taxa in Turkey $(1,2)$. S. sicula, a species of this genus, is widespread throughout Italy, Sicily, Greece, Aegean and East Mediterranean (3). Previous studies on $S$. sicula yielded compounds belonging to the skeletally different groups of Amaryllidaceae alkaloids (4-7). Amaryllidaceae alkaloids display important biological activities including antitumor, antiviral and acetylcholinesterase inhibitory activity (8-12). Although there have been several reports on the phytochemistry and bioactivity of Sternbergia species (13-16), no reports have been recorded in the literature for the quality control determinations on these species, which may establish basis for prospective monographs on Herba and Bulbus drugs prepared from these plants.

Therefore, in the course of our ongoing studies on Sternbergia species of Turkish origin, we car- ried out several quality control assays to determine the quality standarts of drugs prepared from the aerial and underground parts of $S$. sicula collected at two different vegetation periods. European Pharmacopeia was referred to for the gravimetric determinations of humidity, total ash, hydrochloric acid-insoluble ash and sulphated ash and for the titrimetric determinations of the total alkaloidal content (17).

As it is mentioned above, Amaryllidaceae plants and their alkaloids are amply studied for their acetylcholinesterase inhibitory activity (10, 11, 18). Among Amaryllidaceae alkaloids, galanthamine is used in the treatment of Alzheimer's disease (AD) due to its anticholinesterase activity (19). Based on the cholinergic hypothesis, a defect in the cholinergic system is involved in AD (18). Therefore, an important approach to treat Alzheimer's disease (AD) is directed to the inhibition of acetylcholinesterase (AchE). Thus, a search for
AFFILIATIONS

1Ege Üniversitesi Eczacılık Fak, Farmakognozi, İzmir, Türkiye

CORRESPONDENCE

Gülen İrem Kaya

E-mail:

gulen.irem.kaya@ege.edu.tr

Received:

02 July 2010

Revision:

21 July 2010

Accepted:

30 July 2010 


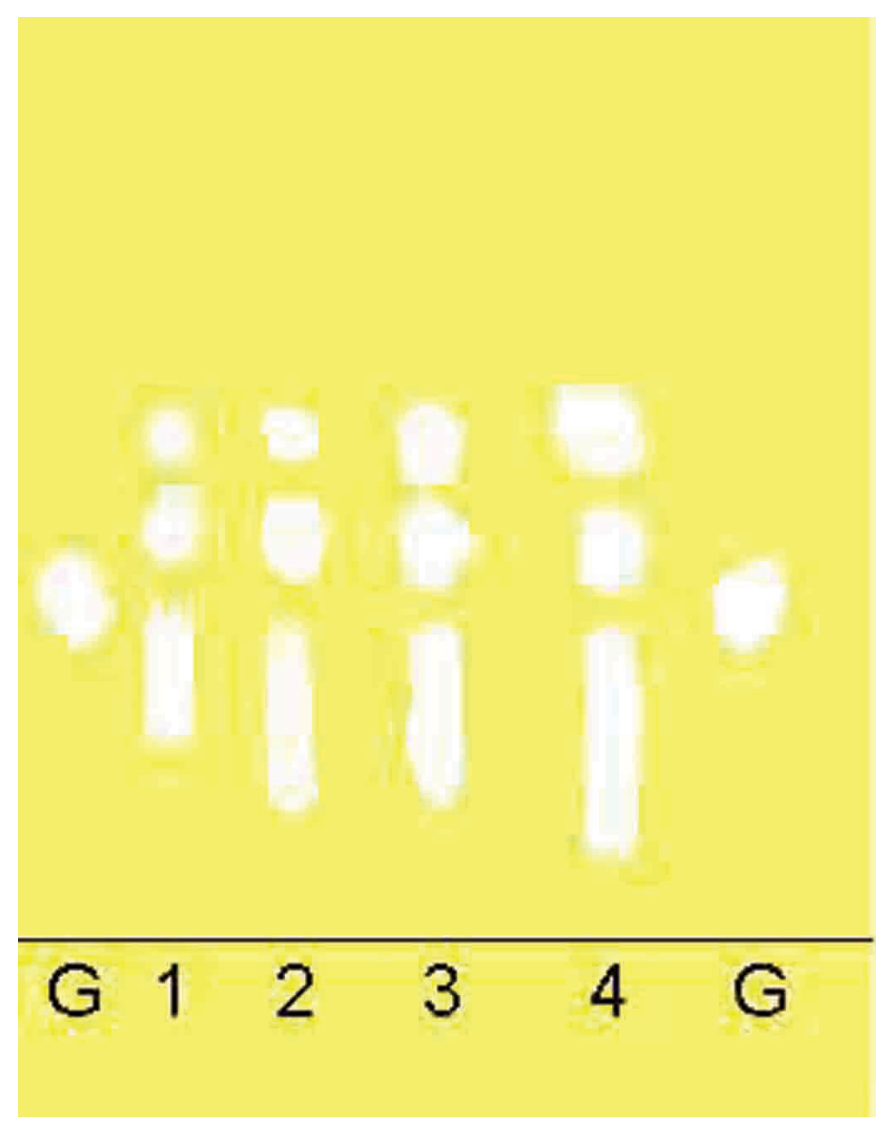

FIGURE 1: Acetylcholinesterase inhibitory activity of alkaloidal extracts of Sternbergia sicula. G: Galanthamine, 1: Bulbus/flowering, 2: Herba/flowering, 3: Herba/ fruiting, 4: Bulbus/fruiting

AchE inhibitors from plants including Amaryllidaceae species has gained importance in the last decade. In this context, alkaloidal extracts prepared from the aerial and underground parts of Sternbergia sicula, collected at two different vegetation periods were screened for their AchE inhibitory activity by using a thin layer chromatography (TLC) assay based on Ellman's method (20) which is a quite simple and also effective method to identify active extracts and/or compounds.

\section{MATERIALS AND METHODS \\ Plant Material}

S. sicula was collected from Söke (Aydın) during flowering and fruiting seasons in November 2007 and March 2008, respectively. The plant was identified by Prof. M. Ali Önür from the Department of Pharmacognosy, Faculty of Pharmacy, Ege University, Izmir (Turkey). Voucher samples of S. sicula (No. 1388,1389 ) are deposited in the Herbarium of the Department of Pharmacognosy, Faculty of Pharmacy, Ege University.

Aerial and underground parts collected during two different vegetation periods, were separated, cut into moderately small pieces and dried in shadow at room temperature.

Humidity, Total Ash, Hydrochloric Acid-Insoluble Ash, Sulphated Ash and Total Alkaloid Content Determinations

European Pharmacopeia was referred to for the gravimetric assays of humidity, total ash, hydrochloric acid-insoluble ash and sulphated ash. The total alkaloid content of each specimen was evaluated by using a titrimetric method cited in European Pharmacopeia for various alkaloid-containing drugs (17).

\section{Alkaloid Extraction}

$6 \mathrm{~g}$ of accurately weighed powdered plant material was macerated with $100 \mathrm{~mL}$ EtOH for 24 hours, and then extracted further with $\mathrm{EtOH}$ until no positive reaction is observed with the Dragendorff and Mayer reagents (17). After evaporation of the solvent, the residue was dissolved in $50 \mathrm{ml}$ portions of $1 \%$ aqueous hydrochloric acid $(250 \mathrm{~mL}$ in total) and filtered. Combined acidic filtrates were washed with 3x100 mL petroleum ether $\left(40-60^{\circ}\right)$, made alkaline with $26 \%$ ammonium hydroxide (pH 9-10) and extracted with 6x100 mL chloroform until the organic solvent displayed no positive reaction with Dragendorff and Mayer reagents. The combined chloroform extracts were then dried over anhydrous $\mathrm{Na}_{2} \mathrm{SO}_{4}$, filtered, and the organic solvent distilled in vacuo to afford the alkaloidal extract. $0.02 \mathrm{~N} \mathrm{H}_{2} \mathrm{SO}_{4}$ solution was added to this extract and kept on water bath $\left(50-60^{\circ} \mathrm{C}\right)$ until the extract was completely dissolved. Then three drops of methyl red reagent (17) was added and the solution was titrated with $0.02 \mathrm{~N} \mathrm{NaOH}$. The procedure was carried out in a series of three parallel experiments. The mean results are given in Table 1.

\section{Chemicals}

Acetylthiocholine iodide (ATCI), Acetylcholinesterase enzyme (AChE) Type VI-S: From Electric Eel, 5,5-dithiobis [2-nitrobenzoic acid] (DTNB) were obtained from Sigma. Tris- $\mathrm{HCl}$ was purchased from Merck. Galanthamine was isolated from several Amaryllidaceae species in our laboratory and authenticated by means of spectral analysis (UV, IR, MS, NMR) (21). The other reagents were of analytical grade.

\section{Acetylcholinesterase Inhibitory Activity Determinations}

TLC assay combined with bioactivity staining for AChE inhibition was modified from a previous study (18). A $2.5 \mathrm{~mm}$ Silica gel plate $\mathrm{F}_{254}(0.2 \mathrm{~mm}$, Aluminium sheet, Merck) was used as a stationary phase. The plant extract $(10 \mathrm{mg} / \mathrm{ml})$ and galanthamine $(1.5 \mathrm{mg} / \mathrm{ml})$ dissolved in chloroform-methanol $(8: 2)$, were spotted on the TLC plate and it is developed in the mobile phase benzene-chloroform-methanol-ammonium hydroxide (26 \%) 8:9:3:2 drops (v/v/v/v). After the plate was dried at room temperature, it was sprayed with $1 \mathrm{mM}$ ATCI and $1 \mathrm{mM}$ DTNB in Tris- $\mathrm{HCl}, \mathrm{pH}: 8$, and upon 3-5 minutes drying, the plate was sprayed with $3 \mathrm{Unit} / \mathrm{ml} \mathrm{AChE}$ in Tris- $\mathrm{HCl}, \mathrm{pH}: 8$. After 20 minutes a yellow background appeared; occurrence of white spots indicated positive reaction.

\section{RESULTS AND DISCUSSION}

In the course of the studies on quality control, humidity, total ash, hydrochloric acid-insoluble ash and sulphated ash were determined for drug specimens prepared separately from plants in flowering and fruiting periods.

The results of the humidity, total ash, hydrochloric acid-insoluble ash and sulphated ash assays suggested that it was appropriate to include these criteria in a prospective monograph on Herba and Bulbus drugs that would be prepared from this plant, and the present findings might be utilized in the establishment of standard values during the elaboration of these monographs (Table 1). 
TABLE 1. Results of the Quality Control Determinations Carried on Sternbergia sicula

\begin{tabular}{|c|c|c|c|c|c|}
\hline Specimen* & Humidity (\%)§ & Total Ash (\%)§ & $\begin{array}{l}\text { Hydrochloric Acid- } \\
\text { Insoluble Ash (\%)§ }\end{array}$ & Sulphated Ash (\%)§ & Total Alkaloids (\%)§ \\
\hline 1 & $\begin{array}{l}8.480 \\
\pm 0.088\end{array}$ & $\begin{array}{l}14.054 \\
\pm 0.201\end{array}$ & $\begin{array}{c}3.113 \\
\pm 0.092\end{array}$ & $\begin{array}{l}23.465 \\
\pm 0.263\end{array}$ & $\begin{array}{c}0.308 \\
\pm 0.011\end{array}$ \\
\hline 2 & $\begin{array}{l}7.828 \\
\pm 0.084\end{array}$ & $\begin{array}{l}9.280 \\
\pm 0.057\end{array}$ & $\begin{array}{l}1.120 \\
\pm 0.103\end{array}$ & $\begin{array}{l}15.117 \\
\pm 0.120\end{array}$ & $\begin{array}{c}0.496 \\
\pm 0.012\end{array}$ \\
\hline 3 & $\begin{array}{r}8.798 \\
\pm 0,067\end{array}$ & $\begin{array}{l}16.924 \\
\pm 0.074\end{array}$ & $\begin{array}{r}4.340 \\
\pm 0.237\end{array}$ & $\begin{array}{l}21.225 \\
\pm 0.211\end{array}$ & $\begin{array}{l}0.122 \\
\pm 0.011\end{array}$ \\
\hline 4 & $\begin{array}{l}8.742 \\
\pm 0,156\end{array}$ & $\begin{array}{l}7.086 \\
\pm 0.038\end{array}$ & $\begin{array}{l}2.659 \\
\pm 0.091\end{array}$ & $\begin{array}{r}11.102 \\
\pm 0.069\end{array}$ & $\begin{array}{l}0.236 \\
\pm 0.007\end{array}$ \\
\hline
\end{tabular}

*1: Bulbus/flowering; 2: Herba/flowering; 3: Herba/fruiting; 4: Bulbus/fruiting

$\S$ Mean Results \pm Standart Deviations

Total alkaloidal content may be used for the evaluation of the quality of Sternbergia sicula. The total alkaloids ranged between $0.122-0.496 \%$ and revealed that maximum values were found in herba of Sternbergia sicula which was collected during flowering season, whereas herba of Sternbergia sicula collected in fruting season displayed minimum values (Table 1). There are only a few reports concerning the quantification of total alkaloids in Sternbergia species (22). However, there is no record in the literature on the quantification of total alkaloids in Sternbergia sicula. Previously, the content of galanthamine, or other alkaloids and the amount of total bases obtained during the isolation studies carried out on some Sternbergia species, have been reported. $(23,24)$. A detailed literature search reveals that lycorine is the most quantified alkaloid in Sternbergia species $(25,26)$. Recently, we have quantitatively determined the content of lycorine in several Amaryllidaceae species including $S$. sicula by HPLC-DAD analysis (27).

In addition to quality control and total alkaloid determinations, anticholinesterase activity of the total alkaloidal extracts prepared from drug specimens were screened by using in vitro Ellman method. The presence of anticholinesterase activity was determined by the formation of well defined white spots made visible by spraying with DTNB/ATCI reagent followed by AchE spray, which gave a yellow background. This assay is a qualitative method for the determination of active extracts and known compounds. All of the alkaloidal extracts prepared from S. sicula displayed anticholinesterase activity (Figure 1).

Previously, during the course of HPLC studies we carried out on this plant, we have not found galanthamine in S. sicula. (28). Therefore, the results of the present study indicate that the alkaloidal extracts prepared from the aerial parts and bulbs of $S$. sicula collected during different vegetation periods, contain alkaloids with anticholinesterase activity other than galanthamine. Moreover, in the literature the very well documentation of the anticholinesterase activity $(18,29)$ of some of the alkaloids found in Sternbergia species (4-7) supports this finding.

\section{ACKNOWLEDGEMENTS}

This work was supported by the Research Fund of Ege University.

Project Number: 09/ECZ/009

\section{REFERENCES}

1. Mathew B, Sternbergia In: Flora of Turkey and the East Aegean Islands. Ed: Davis PH, Edinburgh University Press, Edinburgh. 1984, vol. 8, pp. 360-364.

2. Duman H, Koyuncu M, Ünal F. The Genus Sternbergia Waldst. Kit. (Amaryllidaceae) in Turkey. The Karaca Arboretum Magazine. 6(3): 115-130, 2002.

\section{Sternbergia sicula üzerinde kalite kontrol ve antikolinesteraz aktivite tayin çalışmaları}

ÖZET: Söke (Aydın)'de yabani olarak yetişen Sternbergia sicula Tineo ex Guss. bitkisinin toprak üstü ve toprak altı kısımları çiçekli ve meyveli dönem olmak üzere iki farklı vejetasyon zamanında toplanmıştır. Hazırlanan örnekler üzerinde kalite kontrol çalışmaları ve antikolinesteraz aktivite tayini yapılmıştır. Kalite kontrol çalışmalarının yapıldığı araştırmada, çiçekli ve meyveli vejetasyon dönemlerindeki bitkilerden ayrı ayrı hazırlanan drog örneklerinde nem, total kül, hidroklorik asitte çözünmeyen kül ve sülfat külü deneyleri gerçekleştirilmiştir. Drog örneklerindeki nem, total kül, hidroklorik asitte çözünmeyen kül ve sülfat külü miktarlarının sırasıyla \% 7.828-8.798, \% 7.086-16.924, \%1.1204.340 ve \%11.102-23.465 aralığında değiştiği bulunmuştur. Total alkaloit miktar tayini için, titrimetrik esaslı bir yöntem kullanılmıştır. Total alkaloit miktarı \%0.122-0.496 arasında değişmektedir. En yüksek total alkaloit miktarı çiçekli dönemde toplanan toprak üstü kısımlarında bulunmuştur. En düşük total alkaloit miktarı ise meyveli dönemde toplanan toprak üstü kısımlarında saptanmıştır. Bunlara ilaveten, drog örneklerinden hazırlanan total alkaloit ekstrelerinin antikolinesteraz aktiviteleri in vitro Ellman yöntemine dayalı İnce Tabaka Kromatografisi (i.T.K.) deneyi kullanılarak saptanmıştır. Tüm alkaloit ekstreleri antikolinesteraz aktivite göstermiştir.

ANAHTAR KELIMELER: Sternbergia sicula, Amaryllidaceae, Miktar Tayini, Antikolinesteraz Aktivite 
3. Webb D A, Sternbergia In: Flora Europaea, Editors: Tutin T G, Heywood V H, Burges N A, Moore D M, Valentine D H, Walters S M, Webb D A, Cambridge University Press, Cambridge. 1980, vol. 5, pp. 76.

4. Phokas G K. Alkaloids of Sternbergia sicula. Pharm Acta Helv. 44(4): 257-259, 1969.

5. Pabuççuoğlu V, Richomme P, Gözler T, Kıvçak B, Freyer A J, Shamma M. Four New Crinine- Type Alkaloids from Sternbergia Species. J Nat Prod. 52 (4): 785-791, 1989.

6. Richomme P, Pabuçcuoğlu V, Gözler T, Freyer A J, Shamma M. (-)-Siculinine:A Lycorine-Type Akaloid from Sternbergia sicula. J Nat Prod. 52 (5): 1150-1152, 1989.

7. Kıvçak B, Tekant G. Sternbergia sicula Alkaloitleri. Ege Üniversitesi Eczacılık Fak. Derg. 1(2): 65-71, 1993.

8. Evidente A, Kornienko A. Anticancer Evaluation of Structurally Diverse Amaryllidaceae Alkaloids and Their Synthetic Derivatives. Phytochem Rev. 8: 449-459, 2009.

9. Lamoral-Theys D, Andolfi A, Van Goietsenoven G, Cimmino A, Le Calve B, Wauthoz N, Megalizzi V, Gras T, Bruyere C, Dubois J, Mathieu V, Kornienko A, Kiss R, Evidente A. Lycorine, the Main Phenanthridine Amaryllidaceae Alkaloid, Exhibits Significant Antitumor Activity in Cancer Cells That Display Resistance to Proapoptotic Stimuli: An Investigation of Structure-Activity Relationship and Mechanistic Insight. J Med Chem. 52: 6244-6256, 2009.

10. López S, Bastida J, Villadomat F, Codina C. Acetylcholinesterase Inhibitory Activity of Some Amaryllidaceae Alkaloids and Narcissus Extracts, Life Science, 71: 25192521, 2002.

11. Elgorashi E E, Stafford G I, Staden J V. Acetylcholinesterase Enzyme Inhibitory Effects of Amaryllidaceae Alkaloids. Planta Med. 70: 260-262, 2004.

12. Gabrielsen $B$, Monath $T P$, Huggins J W, Kefauver D F, Petit G R, Groszek G, Hollingshead M, Kirsi J J, Shannon W M, Schubert E M, Dare J, Ugarkar B, Usser M A, Phelan M J. Antiviral (RNA) Activity of Selected Amaryllidaceae; Isoquinoline Constituents and Synthesis of Related Substances. J Nat Prod. 55: 1569-1581, 1992.

13. Tanker N, Çitoğlu G, Gümüşel B, Şener B. Alkaloids of Sternbergia clusiana and Their Analgesic Effects. Int J Pharm. 34(3): 194-197, 1996.

14. Abdalla $S$, Abu Zarga $M$, Sabri S. Alkaloids of Sternbergia clusiana and Effects Lycorine on Guinea- pig Isolated Pulmonary Artery and Heart. Fitoterapia. 64(6): 513-518, 1993.

15. Ünver N, Kaya G İ, Öztürk T. Antimicrobial activity of Sternbergia sicula and Sternbergia lutea. Fitoterapia. 76: 226-229, 2005.
16. Kaya G İ, Sarıkaya B, Çiçek D, Ünver- Somer N. In vitro Cytotoxic Activity of Sternbergia sicula, S. lutea and Pancratium maritimum Extracts. Hacettepe Uni J Fac Pharm. In press, 2010.

17. European Pharmacopoeia, Sixth Edition. 2007, pp. 12611266.

18. Rhee K I, Meent M, Ingkaninan $K$, Verpoorte R. Screening for Acetilkolinesteraz İnhibitors from Amaryllidaceae Using Silica Gel Thin-Layer Cromotography in Combination with Bioactivity Stainning. J. Chromatogr. A. 915: 217-223, 2001.

19. Lilienfeld S. Galanthamine- Anovel Cholinergic Drug with Alzheimer's disease. CNS Drug Rewiews. 8(2): 159176, 2002.

20. Ellman G L, Courtney K D, Andres V, Feather-Stone R M. A New and Rapid Colorimetric Determination of Acetylcholinesterase Activity. Biochemical Pharmacology. 7: 88-95, 1961.

21. Ünver- Somer N, Kaya G İ, Sarıkaya B, Önür M A. Phytochemical Studies on Galanthus woronowii Losinsk. 17th Meeting on Plant Orginated Crude Drugs, Kuşadası. 2007, pp. 87.

22. Abduazimov K A, Yunusov S Y. Alkaloids of Sternbergia lutea. Doklady Akademii Nauk UzSSR. 22(1): 35-36, 1965.

23. Cherkasov O A. Plant Sources of Galanthamine. Research Institute of Medicinal Plants. 11(6): 810-813, 1976.

24. Boit H G, Dopke $W$, Stender W. Alkaloids from Hippeastrum rutilum, Lycoris albiflora, Zephyranthes andersoniana, and Sternbergia fischeriana. Naturwissenschaften. 45: 390, 1958.

25. Çitoğlu G S, Yılmaz B S, Bahadır Ö. Quantative Analysis of Lycorine in Sternbergia Species Growing in Turkey. Chem Nat Comp. 44(6): 826-828, 2008.

26. Evidente A, Iasiello I, Randazzo G. Rapid Quantitative Analysis of Lycorine by Reversed-Phase High- Performance Liquid Chromatography. J Chromatogr. 281: 362366, 1983.

27. Kaya G I, Cicek D, Sarıkaya B, Onur M A, Unver-Somer N. HPLC - DAD Analysis of Lycorine in Amaryllidaceae Species. Nat Prod Com. 5(6): 873- 876, 2010.

28. Çiçek, D. Quality Control Evaluation of Sternbergia sicula Tineo ex Guss. MSc Thesis, Department of Pharmacognosy, Ege University, İzmir. 2010, pp.83-90.

29. Sarkaya B, Kaya G İ, Ünver-Somer N, Önür M A. Acethylcholinesterase Inhibitory Activity Evaluation of Galanthus woronowii. 18th Meeting on Plant Orginated Crude Drugs, İstanbul. 2008, pp.69. 